\title{
Indications for Cesarean Deliveries during a 7-Year Period in a Tertiary Hospital
}

\author{
Indicações para Cesarianas num Hospital Terciário durante Sete Anos
}

\author{
Ana COSTA ${ }^{1}$, Catarina POLICIANO ${ }^{1}$, Nuno CLODE ${ }^{1}$, Luís M. GRAÇA ${ }^{1}$ \\ Acta Med Port 2013 Nov-Dec;26(6):649-654
}

\section{ABSTRACT}

Introduction: To analyze the cesarean section rate evolution in a tertiary hospital and the main indications for cesarean section. Material and Methods: A retrospective study was conducted at a major academic hospital and included 5751 women who had a cesarean section from 2005 to 2011 . The rates of overall, primary and repeat cesarean sections were analyzed. A linear regression and adjusted R-square were used to access the relative contribution of each indication to the variation in primary cesarean section.

Results: During the 7-year period of the study the cesarean section rate decreased from $30.9 \%$ to $27.6 \%$. This was due to a decrease in primary cesarean section (21.9\% to $18.2 \%)$, although an increase in repeat cesarean section was observed $(9.0 \%$ to $9.4 \%)$. Among the indications for primary cesarean section, maternal-fetal indications and malpresentation were the ones that decreased the most with adjusted $\mathrm{R}$-square of 0.70 and 0.55 , respectively.

Discussion: The collected data identified that the decrease in the cesarean section rate at the hospital resulted from a decrease in primary cesarean section deliveries, especially the ones performed for maternal-fetal indications and malpresentation.

Conclusion: The decrease in primary cesarean section rate may be attributed to several changes in medical policies in the Department, such as the implementation of an external fetal version program, the induction of labor only after the 41st week of gestation in low-risk pregnancies and the trial for vaginal birth in maternal-fetal disease. Nevertheless subjective indications such as labor arrest disorders and nonreassuring fetal heart rate are still major contributors for primary cesarean section rate.

Keywords: Cesarean Section; Pregnancy; Pregnancy Complications; Portugal; Tertiary Care Centers.

\section{RESUMO}

Introdução: Analisar a evolução da taxa de cesarianas e as principais indicações para cesariana num centro terciário.

Material e Métodos: Estudo retrospectivo conduzido num hospital universitário que incluiu 5751 grávidas submetidas a cesariana entre 2005 e 2011. Analisaram-se as taxas de cesarianas, incluindo a taxa de primeiras cesarianas e de cesarianas repetidas. Para avaliar a contribuição relativa de cada uma das indicações na variação da taxa de primeiras cesarianas recorreu-se à regressão linear e determinou-se o valor do $r^{2}$ ajustado.

Resultados: Durante o período do estudo a taxa de cesarianas diminuiu de $30,9 \%$ para $27,6 \%$. Esta descida deveu-se à diminuição da taxa de primeiras cesarianas (21,9\% para $18,2 \%)$, apesar de se ter constatado um ligeiro aumento da taxa de cesarianas repetidas $(9,0$ para $9,4 \%)$. Entre as indicações para primeiras cesarianas, as causas materno-fetais e de apresentação anómala foram as que diminuiram mais, com valores de $r^{2}$ ajustado de 0,70 e 0,55 , respectivamente.

Discussão: Os dados coligidos permitiram identificar a hipótese de que a diminuição da taxa de cesarianas se deveria a uma retração detectada sobretudo a nível das primeiras cesarianas, em particular as decorrentes de causas materno-fetais e apresentação anómala.

Conclusão: A diminuição da taxa de primeiras cesarianas pode ser atribuída a várias modificações na prática clínica do Departamento, como a implementação da versão cefálica externa, a indução do trabalho de parto a partir das 41 semanas de gestação, em gravidezes de baixo risco e da realização de provas de trabalho de parto em casos de patologia materno-fetal. No entanto, indicações subjectivas, como a paragem de progressão do trabalho de parto e a suspeita de sofrimento fetal são ainda causas major de primeiras cesarianas.

Palavras-chave: Cesarianas; Gravidez; Complicações da Gravidez; Hospital Terciário; Portugal.

\section{INTRODUCTION}

Cesarean section (CS) rates have been rising worldwide over the past decades. Concern regarding this increase is due to potential maternal and perinatal risks, the possibility of obstetric complications in future pregnancies and financial issues. Therefore, there has been an attempt to define the ideal CS rate but there is no general consensus on this issue. In 1985, the World Health Organization recommended that it should not exceed $15 \% .{ }^{1}$ Nonetheless, differences among countries, primary and tertiary hospitals, such as the resources and the population characteristics, demand that this rate should be adapted to each reality. ${ }^{1}$
In Portugal, according to the National Institute of Statistics, the CS rate per live births has increased from $28.0 \%$ to $36.4 \%$ between 2001 and 2009. The National Health Plan estimates that in 2016 this rate might reach $45.7 \%{ }^{2}$

Several reasons are pointed to contribute to the rising trend of CS: an increase in maternal age, obesity and the presence of other complications, which results in more maternal reasons; the lack of experience of trainees to perform instrumental vaginal deliveries, the sharp decrease in the vaginal birth after cesarean (VBAC) and the fear of litigation. ${ }^{3-6}$ The increase in the CS rate is also due to an increase

\footnotetext{
1. Departamento de Obstetrícia, Ginecologia e Medicina da Reprodução. Hospital de Santa Maria (Centro Hospitalar Lisboa Norte). Lisboa. Portugal.
} Recebido: 08 de Fevereiro de 2013 - Aceite: 30 de Abril de 2013 | Copyright @ Ordem dos Médicos 2013 
in primary CS, since a first cesarean usually determines that subsequent deliveries will be abdominal deliveries. ${ }^{5}$

The objectives of this study were to analyze the CS rate evolution in our Department between 2005 and 2011, to identify the factors that contributed to this evolution and the main indications for primary CS deliveries.

\section{MATERIAL AND METHODS}

We conducted a retrospective study at the Department of Obstetrics, Gynecology and Medicine of Reproduction of Centro Hospitalar Lisboa Norte (CHLN) - Hospital de Santa Maria (HSM), a tertiary hospital that holds an agreement with the University of Lisbon working as a University/Public Hospital.

This study was approved by the Ethics Committee of the institution.

Data was collected about all the CS performed during a 7-year period (2005-2011) from medical records of the Delivery Room and Postpartum Ward. We included information about parity, previous CS, number of fetus in present gestation (single vs. multiple), and the primary indication for CS.

Rates of overall, primary and repeat CS were calculated for each year. CS rates were calculated as the number of cesarean births divided by total live births. Rates for each primary CS indications were calculated annually as the number of primary CS deliveries performed for each indication per 1,000 eligible live births (adjusted for repeat cesarean delivery rate).

In order to facilitate data analysis we combined indications for CS in nine larger representative categories: labor arrest disorders (including arrest of dilation or descent and failure of a trial for instrumental vaginal delivery), suspected fetal distress (in fetal heart tracings or ultrasound evaluations), malpresentation, macrosomia, multiple gestations, maternal-fetal indications, hypertensive disease in pregnancy, repeat cesarean section and other causes. Malpresentation included breech presentation, nonvertex cephalic presentations and transverse lie. Macrosomia was defined as an estimated fetal weight of more than 4,500 g for nondiabetic women and more than $4,000 \mathrm{~g}$ for diabetic women, which were the thresholds for elective CS. Maternal-fetal indications included fetal, maternal or obstetric conditions that contraindicated vaginal birth such as some fetal congenital malformations, cardiac or orthopedic maternal di-. seases and placenta previa or cord prolapsed. Although hypertensive disease in pregnancy (chronic hypertension predating the pregnancy, preeclampsia and eclampsia) is not an isolated indication for elective CS and the decision should take into account obstetric criteria, it was considered a category because of its high frequency. Other causes included all the indications that could not be grouped into one of the other eight categories, such as failed labor induction.

We calculated the relative variation of primary CS and their indications for each year of the study. We assessed the contribution of each indication to the variation in primary CS linear regression and by calculating the adjusted R-square $\left(r^{2}\right)$.

Data analysis was performed using the SPSS version 19.0 (IBM, Armonk, NY, USA).

\section{RESULTS}

From January 2005 to December 2011 there were a total of 19,471 live births in the Hospital de Santa Maria. Of these 5,751 were delivered by CS $(29.5 \%)$.

The evolution of the CS delivery rate during that period of time is shown in Fig. 1. The overall CS delivery rate decreased from $30.9 \%$ in 2005 to $27.6 \%$ in 2011. During the 7-year period of the study, the CS rate decreased each year except for the years 2008 and 2010, when there was a slight increase (from $30.4 \%$ in 2007 to $31.0 \%$ in 2008 and from $28.2 \%$ in 2009 to $28.8 \%$ in 2010 , Fig. 1).

The main indications for CS were labor arrest disorders and maternal-fetal indications (which contributed to $44 \%$ of all CS), followed by repeat CS (20\%), malpresentation $(13 \%)$ and nonreassuring fetal status (12\%). Hypertensive

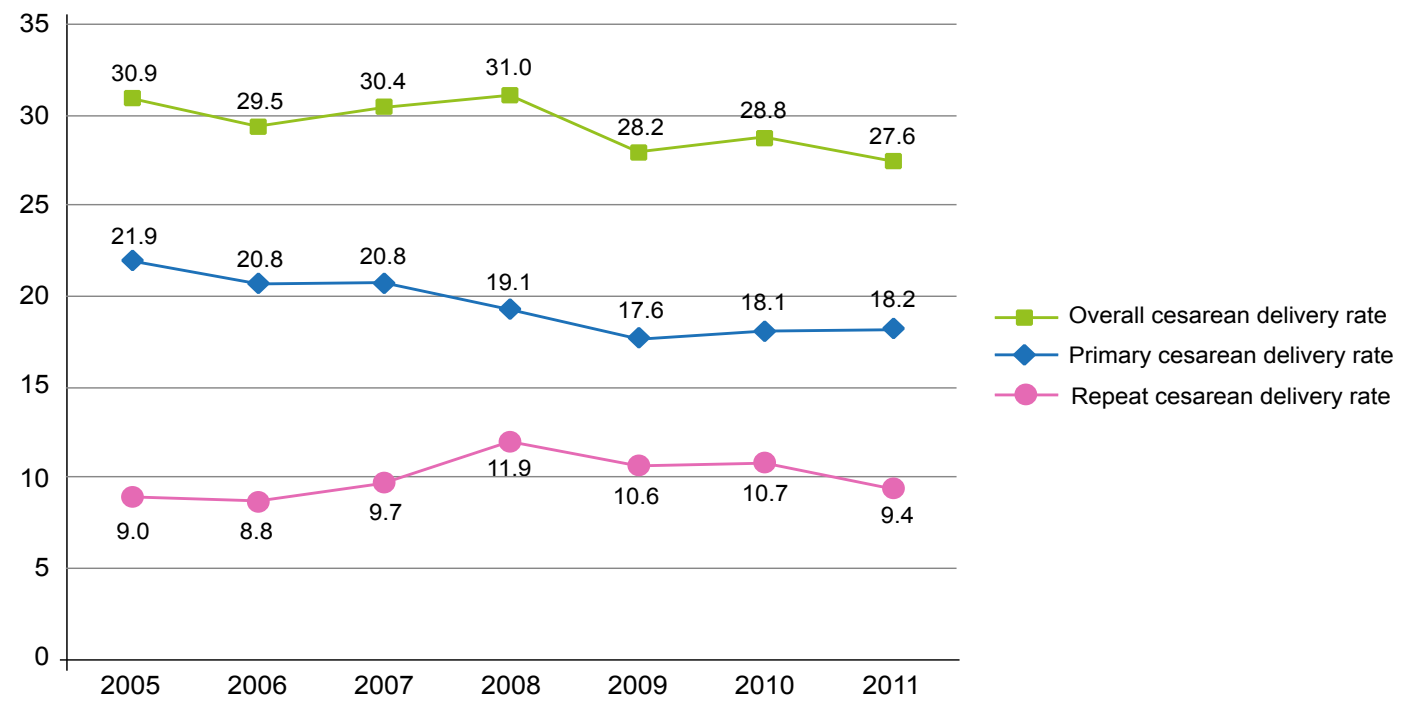

Figure 1 - Evolution of cesarean delivery rates from 2005 to 2011 (\%). 


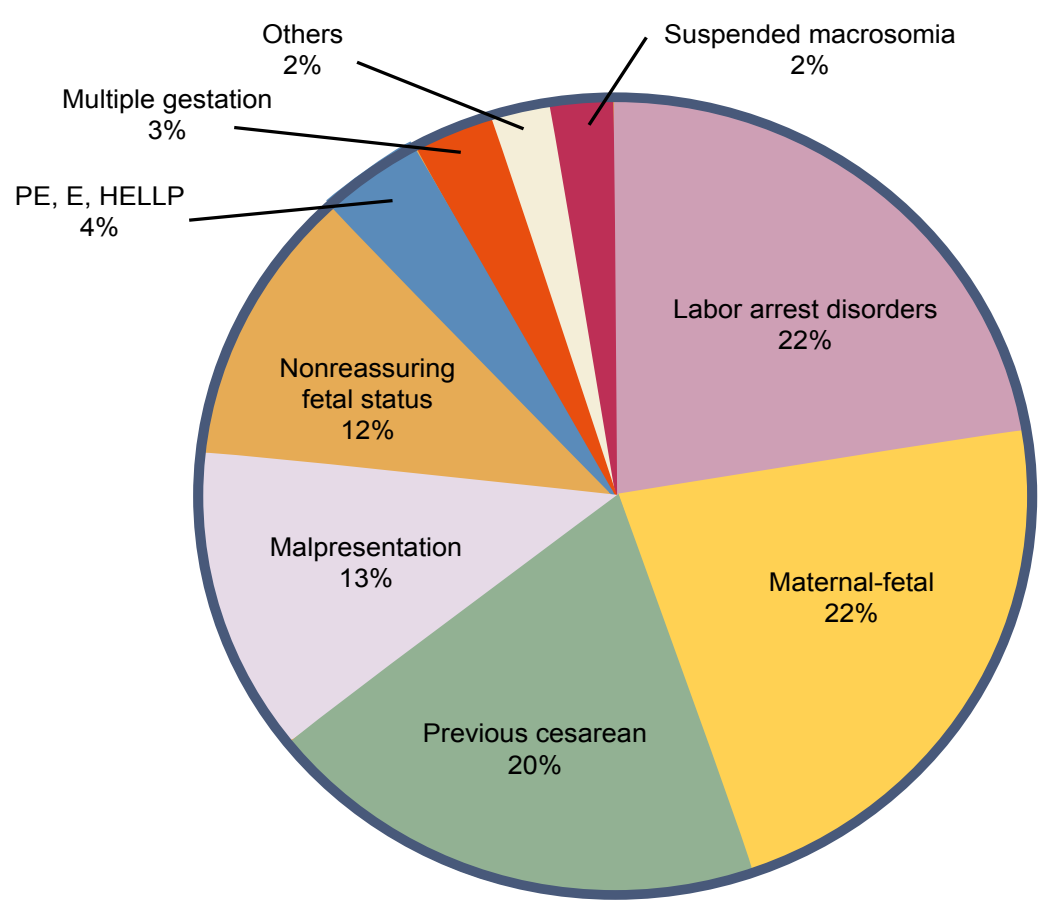

Figure 2 - Distribution of all indications for overall cesarean deliveries.

$\mathrm{PE}$, preeclampsia; E, eclampsia; HELLP, hemolysis, elevated liver enzymes and low platelets.

disorders, multiple gestation and suspected macrosomia accounted for about $9 \%$ of the CS delivery rate (Fig. 2).

The overall repeat CS rate increased from $9.0 \%$ in 2005 to $9.4 \%$ in 2011 (Fig.1). There was an increase of the repeat CS rate from $2006(8.8 \%)$ to $2008(11.9 \%)$, but after that it decreased to $10.6 \%$ in 2009 and to $9.4 \%$ in 2011 .

The primary CS rate decreased steadily from 2005 to 2009, followed by a small increase until 2011 (from 17.6\% in 2009 to $18.2 \%$ in 2011). Despite this, from 2005 to 2011 there was a decrease in the overall primary CS rate from $21.9 \%$ to $18.2 \%$.

Since the primary CS deliveries were responsible for the decrease in the CS rate we analyzed the variation of primary CS performed by all indications (Fig.s 3a and 3b). The main indications for primary CS prevailed during this period and were labor arrest disorders, maternal-fetal indications, malpresentation and nonreassuring fetal status. From 2005 to 2011 the primary CS deliveries had a mean annual relative decrease of $2.83 \%$, (95\% confidence interval [Cl] -6.51 to 0.85 ) (Table 1). Among all the indications for CS, maternal-fetal conditions and malpresentation were the ones that decreased the most with an average annual decrease of $6.40 \%$ (95\% confidence interval [Cl] -16.88 to 4.08$)$ and $1.84 \%(95 \%$ confidence interval [Cl] -14.29 to 10.62 ), respectively. We verified an increase in primary CS performed for hypertensive disorders (average annual increase $10.12 \%$ (95\% confidence interval $[\mathrm{Cl}]-11.94$ to 32.17).

Among the documented causes for primary CS, maternal-fetal indications and malpresentation where the ones which correlated the better with the decrease in the primary
CS rate, with adjusted R-square of 0.70 and 0.55 , respectively.

\section{DISCUSSION}

According to our data the decrease in the CS rate at our hospital was due to a decrease in primary CS deliveries, especially the ones performed for maternal-fetal indications and malpresentation.

During the study period a series of measures were implemented in our department to decrease the CS rate. These include the practice of external cephalic version (ECV), the induction of labor only after the $41^{\text {th }}$ week of gestation in low-risk pregnancies and the trial of vaginal birth after a cesarean section (VBAC). The continuous training of the residents in the use of forceps and vacuum extractor and a more expectant management of labor may have also contributed to our results.

The decrease of CS performed for maternal-fetal indications might be due to the use of induction of labor for some obstetric indications such as colesthasis of pregnancy, olygoamnios and fetal growth restriction, when there was no contraindication for vaginal delivery. Therefore, by inducing these women in a tertiary center, we ensured that labor would occur with maximum support of the obstetric team and allowed a vaginal birth.

The reduction of CS delivery for malpresentation could be due to the practice of external cephalic version. In our Department, the procedure is done after the $36^{\text {th }}$ week and the success rate of ECV is $44.4 \%{ }^{7}$

The criteria for diagnosing labor arrest disorders in the first and second stage of labor remains controversial. ${ }^{3-8}$ 


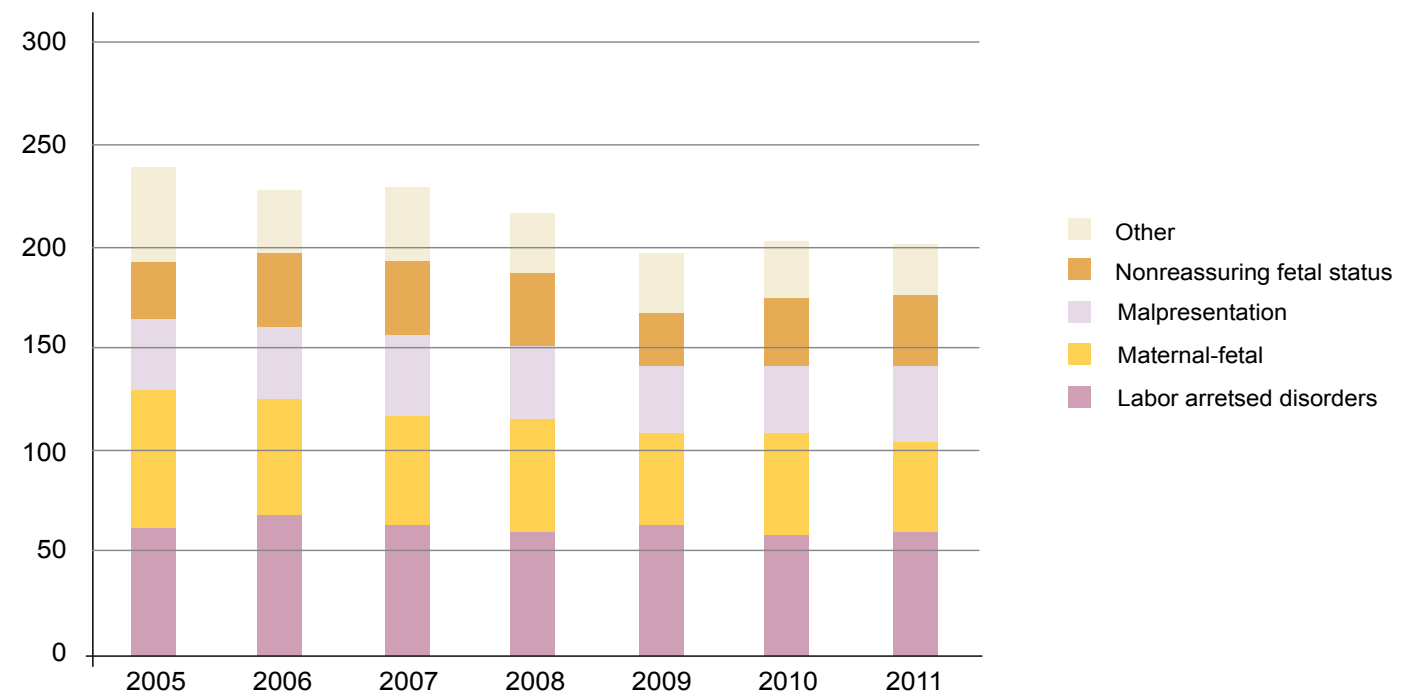

Figure 3a - Number of primary cesarean deliveries performed for 1,000 eligible live births. Primary cesarean sections performed from 2005 to 2011 for each indication. The 'other' category is described in (b).

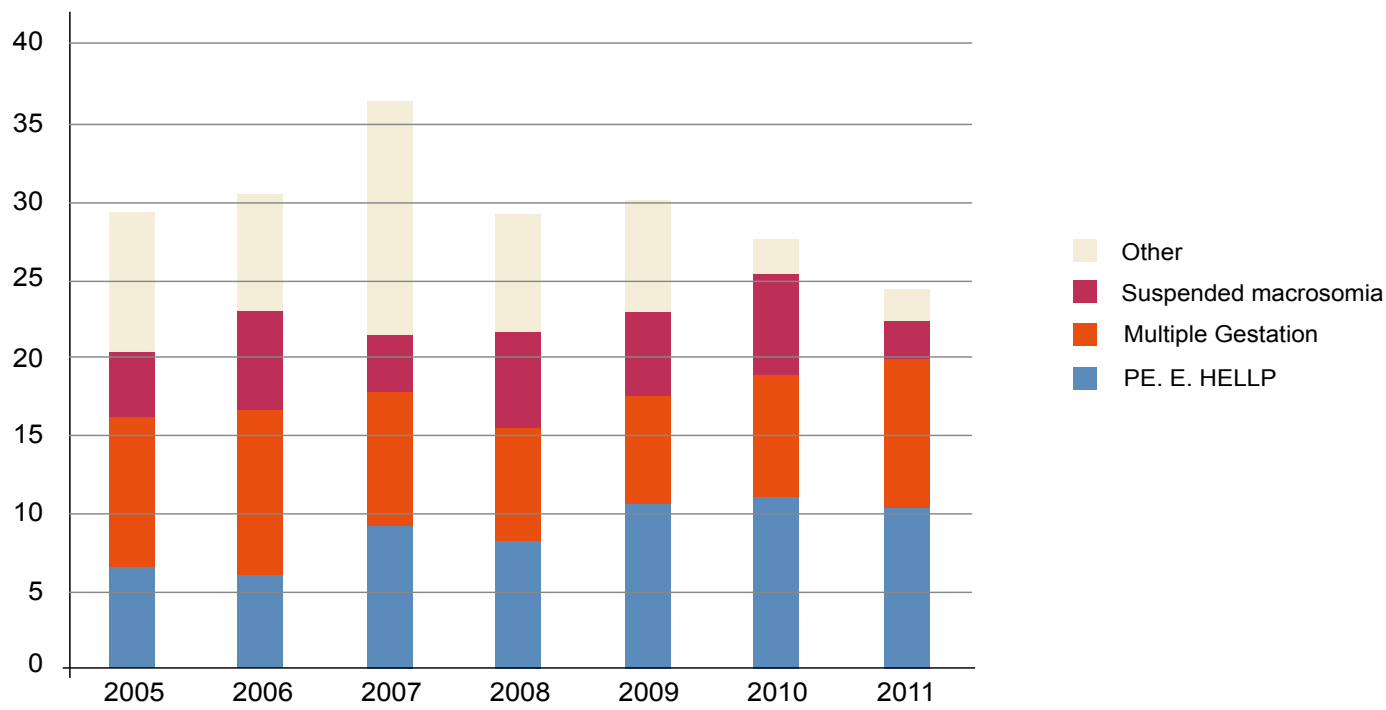

Figure $3 \mathrm{~b}$ - Number of primary cesarean deliveries performed for 1,000 eligible live births. Primary cesarean sections performed from 2005 to 2011 for each indication. The 'other' category represented in (a) is described, with a smaller scale. Eligible live births were births to women with no previous cesarean delivery.

PE, preeclampsia; E, eclampsia; HELLP, hemolysis, elevated liver enzymes and low platelets.

During the study period, the relative contribution of labor arrest disorders for CS has decreased. We were not able to verify which CS were performed for arrest of dilation, a more subjective indication, or arrest of descent. However, a more expectant management of labor in order to achieve vaginal delivery could explain this decrease..$^{8-10}$ This may be important since many women may not be in active phase until $6 \mathrm{~cm}$ of dilatation. ${ }^{8,11}$ Furthermore, we frequently used oxytocin whether to induce or enhance labor, while continuously monitoring the fetal heart rate. Also, when indicated, we performed instrumental deliveries in cases of arrest of descend to avoid potential risks associated with full dilatation $\mathrm{CS}^{3}$

Cesarean deliveries performed for macrosomia have had a mean annual decrease of only $0.32 \%$. Although there has been a great variation through the years in the CS per- formed for macrosomia, the overall relative decrease of CS due to macrosomia might be because physicians follow specific criteria to deliver suspected macrosomic fetus.

During the time period of our study, CS performed for nonreassuring fetal status, hypertensive disorders, and multiple gestations have increased. The high variability in the interpretation of fetal heart tracings and fear of litigation could have influenced the decision for a CS in these situations. As for preeclampsia, international guidelines state that labor should be induced, unless there is any obstetric indication for CS. ${ }^{12,13}$ Still, the relative contribution of these indications for primary CS rate might indicate the use of CS rather than induction of labor to manage these situations. The increasing incidence of twins and higher-order multiple gestations over the past years due to medically assisted reproductive techniques might explain the increase in the 


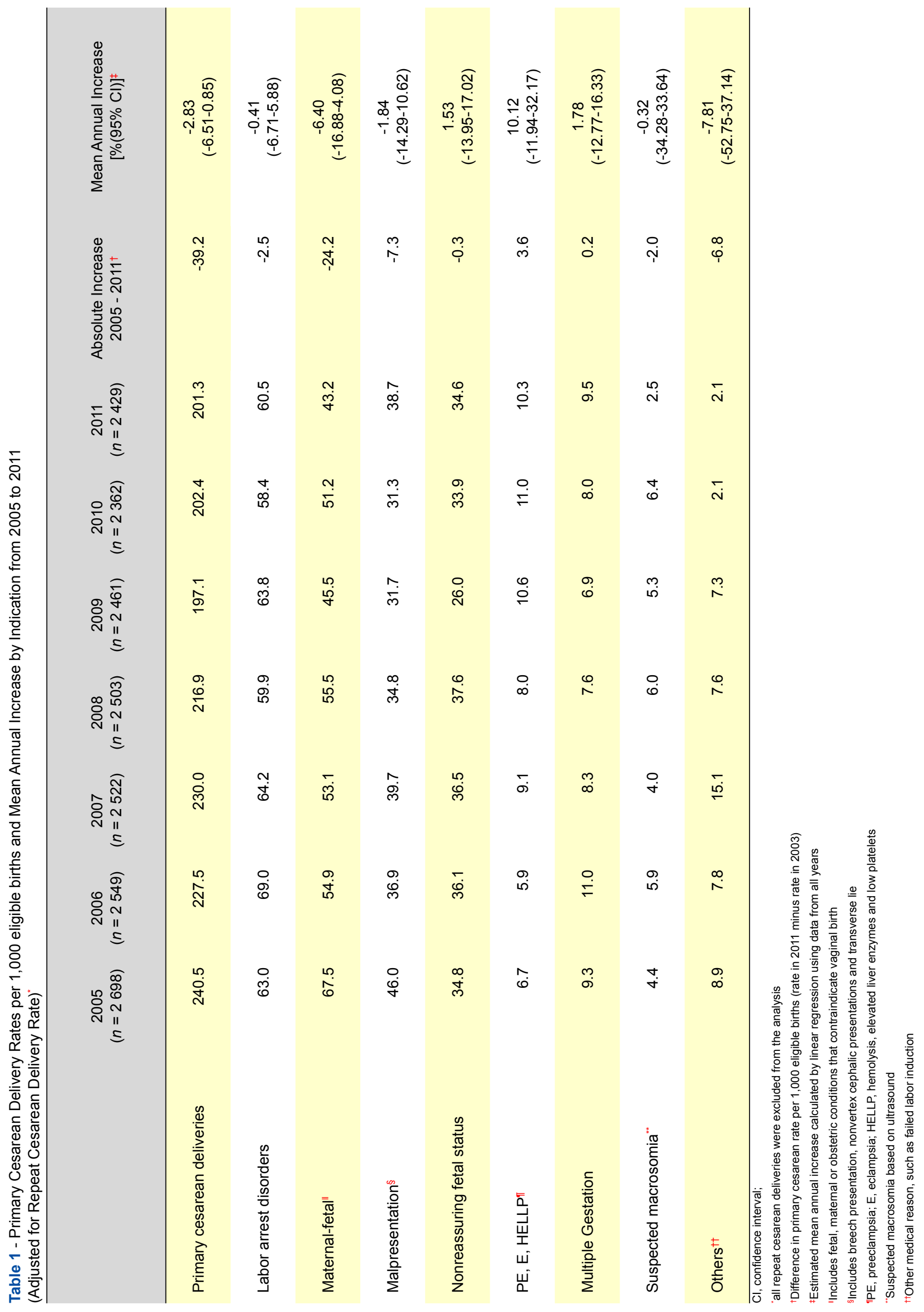


CS performed for these indications.

Finally, from 2005 to 2011 we verified an increase in the repeat cesarean rate, despite there is general consensus that the benefits of VBAC outweigh the risk of repeated CS in most women. ${ }^{5}$ Since it is a safe procedure when performed in selected patients, we offered VBAC to all pregnant women who were eligible for a trial of labor. Nonetheless, we did not induce labor in women with a prior abdominal delivery and a CS was performed systematically after the 41th week of pregnancy if labor didn't occur spontaneously. This might explain the increase in the repeated CS.

As this is a retrospective study and data was collected from medical records, there could have been errors in the classification of CS. We used a classification based on the indications to the CS to analyze the specific contribution of each indication to the variation in the CS rate. However, this is a highly subjective classification system and CS might have been performed for more than one indication. ${ }^{14}$ Other classification systems could have been used such as the ten-group classification, proposed by Robson, which is useful to assess the characteristics of the women that contribute the most to the CS rate. ${ }^{6,15}$ Also, we could not analyze the demographic and obstetrics characteristics of our population. The data collected represents a single institution in Portugal so cannot be generalized to other populations.

\section{CONCLUSION}

Despite the mentioned limitations, this study is important as it reflects the efforts of one-single institution in reducing CS rates. Avoiding the first CS increases the probability of a vaginal birth in a subsequent pregnancy and decreases the adverse events associated with cesarean delivery. ${ }^{16,17}$ Although this study was not able to assess the causal effect of all the measures implemented in our department to decrease CS rates, we could infer that they had a beneficial impact in the CS rate. Practice in operative deliveries, vaginal twin deliveries and external cephalic version should continue and VBAC should be offered to selected patients. Efforts should be done to improve the interpretation of fetal heart tracings, to assess labor arrest disorders and to estimate fetal weight accurately. Hypertensive disorders should be managed correctly and elective CS should be performed only if induction of labor is contraindicated. Regular audits must be made to assess whether abdominal deliveries were appropriated in each case. 6,10

Although it is important to reduce CS rates in order to improve maternal and neonatal outcomes, CS rates that are too low may be associated to increased adverse events, especially when we consider tertiary and referral centers, such as our institution. Therefore, caution should be taken when considering a $15 \%$ CS rate, as this may be too low. ${ }^{6,10,18}$ Finally, it is important to involve the patient in all medical decisions whenever possible and to increase patient education in order to avoid litigation. ${ }^{17}$

\section{CONFLICT OF INTERESTS}

None stated.

\section{FUNDING SOURCES AND FURTHER INFORMATION}

This work was previously delivered as a Poster at the $17^{\text {th }}$ World Congress on Controversies in Obstetrics, Gynecology and Infertility. Lisbon, 8 to 11 de November, 2012.

\section{REFERENCES}

1. Gibbons L, Belizan JM, Lauer JA, Betran AP, Merialdi M, Althabe F. Inequities in the use of cesarean section deliveries in the world. Am J Obstet Gynecol. 2012;206:331.e1-19.

2. General Health Department. National Health Plan 2012-2016: Health Indicators and goals. [Accessed $2012 \mathrm{Nov}$ 15]. Available at URL: http://pns.dgs.pt/files/2012/02/Indicadores_e_Metas_em_Saude1.pdf Published 2011.

3. Untersheider J, McMenamin M, Cullinane F. Rising rates of cesarean deliveries at full dilatation: a concerning trend. Eur J Obstet Gynecol Reprod Biol. 2001;157:141-4.

4. Dresang TL, Leeman L. Cesarean delivery. Prim Care Clin Office Pract. 2012;39:145-65.

5. MacDorman M, Declerq E, Menacker F. Recent trends and patterns in cesarean and vaginal birth after cesarean (VBAC) deliveries in the United States. Clin Perinatol. 2011;38:179-92.

6. Robson MS. Can we reduce the caesarean section rate? Best Pract Res Clin Obstet Gynaecol. 2001;15:179-94.

7. Fadigas C, Santo S, Clode N, Pinto L, Graça LM. External cephalic version: experience of a maternal-fetal unit. Acta Obstet Ginecol Port. 2011;5:3-7.

8. Zhang J, Troendle J, Reddy UM, Laughon SK, Branch DW, Burkman R, et al. Contemporary cesarean delivery practice in the United States. Am J Obstet Gynec. 2010;203:326.e1-10.

9. Mancuso MS, Dwight JR. Cesarean delivery for abnormal labor. Clin Perinatol. 2008;35:479-90.

10. Delbaere I, Cammu H, Martens E, Tengy I, Martens G, Temmerman M. Limiting the caesarean section rate in low risk pregnancies is a key to lowering the trend of increased abdominal deliveries: an observational study. BMC Pregnancy Childbirth. 2012;12:3.

11. Zhang J, Troendle J, Mikolajczyk R, Sundaram R, Beaver J, Fraser W. The natural history of the normal first stage of labor. Obstet Gynecol. 2010;115:705-10.

12. American College of Obstetrics and Gynecologists. ACOG Committee on Obstetric Practice. ACOG Practice Bulletin. Diagnosis and management of preeclampsia and eclampsia. Int J Gynaecol Obstet. 2002;77:67-75.

13. Sibai BM. Management of late preterm and early-term pregnancies complicated by mild gestacional hypertension/ pre-eclampsia. Semin Perinatol. 2011;35:292-6.

14. Torloni MR, Betran AP, Souza JP, Widmer M, Allen T, Gulmezoglu M, et al. Classifications for cesarean section: a systematic review. PLoS ONE. 2011;6:e14566.

15. Robson MS. Classification of cesarean section. Fetal Maternal Med Rev 2001;12:23-39.

16. Jackson S, Fleege L, Fridman M, Gregory K, Zelop C, Olsen J. Morbidity following primary cesarean delivery in the Danish National Birth Cohort. Am J Obstet Gynecol. 2012;206:139.e1-5.

17. Marshall NE, Fu R, Guise J-M. Impact of multiple cesarean deliveries on maternal morbidity: a systematic review. Am J Obstet Gynecol. 2011;205:262.e1-8.

18. Barber EL, Lundsberg LS, Belanger K, Pettker CM, Funai EF, Illuzi JL. Indications contributing to the increasing cesarean delivery rate. Obstet Gynecol. 2011;118:29-38. 
Ana COSTA, Catarina POLICIANO, Nuno CLODE, Luís M. GRAÇA

\section{Indications for Cesarean Deliveries during a 7-Year Period in a Tertiary Hospital \\ Acta Med Port 2013:26:649-654}

Publicado pela Acta Médica Portuguesa, a Revista Científica da Ordem dos Médicos

Av. Almirante Gago Coutinho, 151

1749-084 Lisboa, Portugal.

Tel: +351218428 215

E-mail: submissao@actamedicaportuguesa.com

www.actamedicaportuguesa.com

ISSN:0870-399X | e-ISSN: 1646-0758

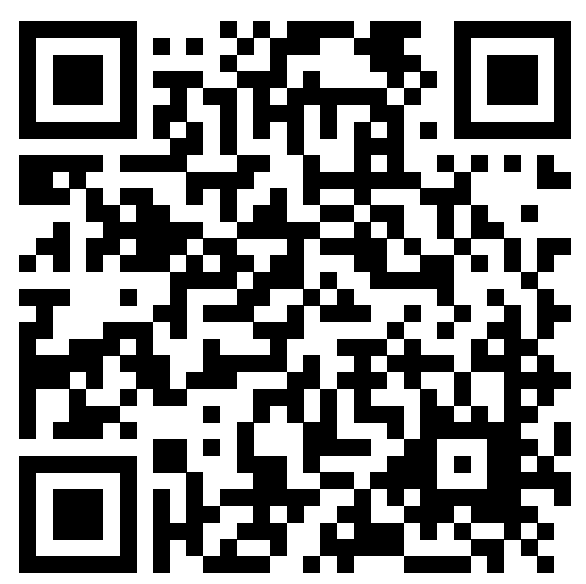

